\title{
Governance Structure, Social Emotional Wealth and Family Firm Innovation
}

\author{
Min Zhao ${ }^{1,2, a}$, Xin $\mathrm{Yao}^{3, \mathrm{~b}}$ \\ ${ }^{1}$ China National Institute of Standardization, Beijing 100191, China \\ ${ }^{2}$ Tsinghua University, Beijing 100083, China \\ ${ }^{3}$ CCPIT Commercial Sub-council, Beijing 100801, China \\ azhaomin@cnis.gov.cn, byaoxin@ccpit.org
}

Keywords: Governance Structure, Social Emotional Wealth(SEW), Family Firm, Innovation.

\begin{abstract}
Innovation is important to the sustainable development of family firm. From the subjective and objective perspectives, this paper uses multiple regression model to analyze the impact of family involvement and social emotional wealth (SEW) on family firm innovation. This is an attempt and breakthrough in the research on the theory crossover and heterogeneity in the field of family firm innovative.
\end{abstract}

\section{Introduction}

Family firm faces the challenge of intergenerational inheritance, governance improvement and fierce competition in the market. Innovation is important to the sustainable development of family firm. Governance structure is an important source of heterogeneity of family firm[1], and it is also a key objective factor that influences family firm innovation. Socio emotional Wealth (SEW) pursues family-centered non-economic goals and is an important reference for family firm to make strategic decisions and manage their operations.[2]. It is an important subjective influencing factor that affects family firm innovation. This article tries to study how the governance structure (objective factor) and social emotional wealth(subjective factor) act together and influence family firm innovation.

\section{Theoretical Analysis and Research Hypothesis}

The governance structure has an impact on the family firm innovation mainly through family involvement, and its influence is heterogeneous[2]. Agency theory believes that the family will invest in family firm, and highly single ownership involved will increase the risk aversion of family firm owners; Family involvement in the board of directors helps to reduce the agency problem between the family firm and the senior management team. It plays an active role in promoting high-risk and high-return research activities while ensuring the rational use of external resources through external directors. This governance mechanism has enhanced the effectiveness of R\&D investment. Management involvement seizes the innovative input capital by grabbing the enterprise resources, and the inclusion of family management will bring the cronyism and nepotism. Suppressing the sharing of internal knowledge resources will often inhibit the innovation investment of family firm. In summary, this paper proposes the research hypothesis:

H1: Family involvement has a heterogeneous impact on family firm innovation.

H1a: The degree of family equity involvement is negatively related to family firm innovation.

H1b: The degree of family board involvement is positively related to family firm innovation.

H1c: The degree of family management involvement is negatively related to family firm innovation.

The social emotional wealth (SEW) is a combination of various family emotional benefits obtained from the firm. It is a complex multidimensional concept that needs to be analyzed heterogeneously to explain the difference in the role of different social emotional wealth in innovation. Gomez Mejia et al. introduced the Mixed Gamble model[4]. They dispelled the conflicts of different social emotional wealth (SEW) in the trade-off between policy makers. Different type of social emotional 
wealth (SEW) tends to lead to different strategic decisions. Miller and Le Breton-Miller (2014) Conducted a heterogeneous analysis of SEW intentions[4]. They categorized SEW into two dichotomous types: restricted SEW and extended SEW. The controlling family with a restricted SEW intention is characterized as having a narrow, short-term perspective of noneconomic benefits and always lack of innovation. On the other hand, the family with an extended SEW intention employs a broad and enduring perspective of benefits always tends to innovate. In summary, this paper proposes the research hypothesis:

Hypothesis 2: Different type of SEW has different impact on family firm innovative.

Hypothesis 2a: The degree of restricted SEW is negatively related to family firm innovation.

Hypothesis 2c: The degree of extended SEW is positively related to family firm innovation.

\section{Research Design}

\subsection{Data Selection and Variable Settings}

The research data mainly comes from the national private enterprises sampling survey database (2012). According to the definition of family firm, this paper screened the family firm data and finally obtained 893 data observations. According to the above theoretical research, this paper takes the R\&D intensity as dependent variable, and takes family involvement and SEW as independent variable. Family involvement variables include family equity involvement, family board involvement and family management involvement variables. SEW variables include restricted SEW and extended SEW.

Table 1. variable definition

\begin{tabular}{|c|c|c|c|c|}
\hline Types of & name & variable & Code & Measurement indicators and coding \\
\hline $\begin{array}{l}\text { Dependent } \\
\text { variable }\end{array}$ & $\mathrm{R} \& \mathrm{D}$ intensity & $\mathrm{R} \& \mathrm{D}$ intensity & $\mathrm{RD}$ & $\begin{array}{c}\text { The ratio of R\&D investment and owner's } \\
\text { equity }\end{array}$ \\
\hline \multirow{5}{*}{$\begin{array}{l}\text { Independent } \\
\text { variable }\end{array}$} & \multirow{3}{*}{ Governance structure } & $\begin{array}{c}\text { Family equity } \\
\text { involvement }\end{array}$ & FO & The proportion of family owners' equity \\
\hline & & $\begin{array}{l}\text { Family board } \\
\text { involvement }\end{array}$ & FB & $\begin{array}{l}\text { The proportion of family members in the } \\
\text { board }\end{array}$ \\
\hline & & $\begin{array}{c}\text { Family management } \\
\text { involvement }\end{array}$ & FM & $\begin{array}{l}\text { Family members as president, general } \\
\text { manager, etc., recorded as } 1 \text {, otherwise } 0\end{array}$ \\
\hline & \multirow{2}{*}{$\begin{array}{l}\text { Social emotional } \\
\text { wealth } \\
\text { (SEW) }\end{array}$} & Restricted SEW & FCI & $\begin{array}{l}\text { "Do you agree with the family should have } \\
\text { more than } 50 \% \text { stake " and other six items } \\
\text { code value and sum }\end{array}$ \\
\hline & & Extended SEW & FSI & $\begin{array}{l}\text { "Have you considered the issue of child } \\
\text { succession" and "Your child has no intention } \\
\text { of succession" two items, code value and sum }\end{array}$ \\
\hline \multirow{9}{*}{$\begin{array}{c}\text { Control } \\
\text { variables }\end{array}$} & \multirow{3}{*}{$\begin{array}{l}\text { Entrepreneurial } \\
\text { characteristics }\end{array}$} & Age & AGE & Age of entrepreneurs \\
\hline & & Gender & GENDER & $\begin{array}{l}\text { The gender of the entrepreneur, } 1 \text { for men and } \\
0 \text { for women }\end{array}$ \\
\hline & & Education level & EDU & $\begin{array}{l}\text { Entrepreneurship education, from elementary } \\
\text { school to graduate school and above, code 1- } \\
6 \text { in order }\end{array}$ \\
\hline & \multirow{6}{*}{$\begin{array}{c}\text { Firm } \\
\text { characteristics }\end{array}$} & Years & F_AGE & $\begin{array}{l}\text { From before } 1989 \text { to after 2005, code 1-5 in } \\
\text { order }\end{array}$ \\
\hline & & Size & SIZE & 0 to more than 100 million, code $1-7$ in order \\
\hline & & Asset liability ratio & LEV & 0 to $50 \%$ or more, code $1-5$ in order \\
\hline & & Diversification & DIVER & Number of industries entered \\
\hline & & Net profit & NT & Net profit of the year \\
\hline & & $\begin{array}{c}\text { Industry dummy } \\
\text { variables }\end{array}$ & IND & $\begin{array}{l}\text { Industry type, with dummy variables to } \\
\text { represent }\end{array}$ \\
\hline
\end{tabular}




\subsection{Model Settings}

According to the research hypothesis, the article set up a multiple regression model as follows:

$$
\begin{aligned}
& R D_{i t}=\alpha+\beta_{1} A G E_{i t}+\beta_{2} G E N D E R_{i t}+\beta_{3} E D U_{i t}+\beta_{4} F_{-} A G E_{i t}+\beta_{5} S I Z E_{i t}+\beta_{6} L E V_{i t}+\beta_{7} D I V E R_{i t}+\beta_{8} N T_{i t}+ \\
& \beta_{9} F O_{i t}+\beta_{10} F B_{i t}+\beta_{11} F M_{i t}+\sum I N D_{-} d u m m y+\varepsilon_{i t} \\
& R D_{i t}=\alpha+\beta_{1} A G E_{i t}+\beta_{2} G E N D E R_{i t}+\beta_{3} E D U_{i t}+\beta_{4} F_{-} A G E_{i t}+\beta_{5} S I Z E_{i t}+\beta_{6} L E V_{i t}+\beta_{7} D I V E R_{i t}+\beta_{8} N T_{i t}+ \\
& \beta_{9} F O_{i t}+\beta_{10} F B_{i t}+\beta_{11} F M_{i t}+\beta_{12} F T_{i t}+\beta_{13} F C I_{i t}+\beta_{14} F S I_{i t}+\sum I N D_{-} d u m m y+\varepsilon_{i t}
\end{aligned}
$$

\section{Empirical Results}

The results of Model 1 show that the impact of family involvement is heterogeneous. There is a significant negative correlation between family equity involvement and R\&D intensity (coefficient 0.001, $\mathrm{P}<0.01$ ), indicating that a high family equity involvement would increase the risk aversion and reduce innovation. There is a positive correlation between the family board involvement and $R \& D$ intensity $(\mathrm{R}=0.023, \mathrm{P}<0.1)$, indicating that the higher the proportion of family members in the board, the more conducive to innovation; the relationship between family management involvement and innovation is not Significant. Therefore, Hypothesis 1, Hypothesis 1a, Hypothesis $1 \mathrm{~b}$ are validated, and Hypothesis $1 \mathrm{c}$ is not verified.

The results of model 2 show that restricted SEW is negatively correlated with innovation (coefficient -0.002, $\mathrm{P}<0.1$ ), indicating that the family firm holding restricted SEW pay more attention to short-term losses caused by innovative and tend to evade innovation. However, extended SEW is positively correlated with innovation (coefficient 0.026, $\mathrm{P}<0.1$ ), indicating that the family firm holding extended SEW pay more attention to the win-win between the family and the stakeholders. They are more tolerant of short-term losses caused by R\&D and tend to innovate. Hypothesis 2, Hypothesis 2a and Hypothesis $2 \mathrm{~b}$ are verified.

Table 2. regression analysis results

\begin{tabular}{ccc}
\hline variable & Model 1 & Model 2 \\
\hline FO & $-.001^{* * *}(-3.221)$ & $-.001^{*}(-0.953)$ \\
FB & $.023^{*}(1.52)$ & $.024^{*}(0.589)$ \\
FM & $-0.005(-0.356)$ & $0.016(0.459)$ \\
FRI & & $-.002^{*}(-1.306)$ \\
FEI & $.003^{*}(2.17)$ & $.026^{*}(1.187)$ \\
AGE & $-0.009(-0.342)$ & $.002^{*}(1.477)$ \\
GENDER & $.017^{* * *(1.771)}$ & $-0.013(-0.515)$ \\
EDU & $0.002(0.169)$ & $.011^{* * *}(1.141)$ \\
F_AGE & $-0.017(-1.882)$ & $0.002(0.151)$ \\
SIZE & $.019^{* * *}(3.274)$ & $-0.017(-1.876)$ \\
LEV & $-0.018(-1.616)$ & $.016^{* * *}(2.686)$ \\
DIVER & $-0.001(-0.513)$ & $-0.019(-1.713)$ \\
NT & $0.185(1.296)$ & $-0.001(-0.064)$ \\
constant & 0.227 & $0.051(-0.335)$ \\
R side & 0.122 & 0.284 \\
Adjust R side & 2.173 & 0.159 \\
F & 2.269 \\
\hline
\end{tabular}

Note: ${ }^{* * *} \mathrm{P}<0.01,{ }^{* *} \mathrm{P}<0.05, * \mathrm{P}<0.1$, the numbers in parentheses are $\mathrm{t}$ values.

\section{Conclusion}

This paper studies the influential factors of family firm innovation, and explores the impact of subjective and objective factors on the innovation from the perspectives of family governance structure and social emotional wealth (SEW). Through data analysis, most of the hypotheses have been verified in this paper, but the impact of family management involvement on innovation is not 
significant. This may be because the impact of family management involvement on innovation is more complex than the study of the paper. Judging from the theoretical deduction, family management involvement has a restraining effect on innovation. At the same time, the duality can innovate more rapidly and thoroughly and achieve good results. The duality structure belongs to one kind of family involvement, so different kind of family management involvement have different effects. In the future research, we should further study the heterogeneity of family management involvement and truly explore the mechanism in family firm innovation.

\section{Acknowledgments}

This work is supported by Dean Foundation of China National Institute of Standardization (572018Y-5938).

\section{References}

[1]. Chua, Chrisman, Steier, et al. Sources of heterogeneity in family firms: an introduction. Entrepreneurship Theory and Practice. 2012(36):1103-1113.

[2]. Gomez Mejia, Cruz, et al. The Bind that Ties: Socioemotional Wealth Preservation in Family Firms. Academy of Management Annals.2011(5): 653-707.

[3]. Zhou Li-xin. Family Involvement and Innovative Capabilities of Family Enterprises: An Empirical Study of Family-owned Manufacturing Enterprises in China. Research and Development Management. 2014 (1): 136-144.

[4]. Gomez Mejia, Campbell, et al. Socioemotional Wealth as a Mixed Gamble: Revisiting Family Firm Investments with the Behavioral Agency Model. Entrepreneurship Theory and Practice. 2014(38): 1351-1374.

[5]. Miller, Le Breton Miller. Deconstructing socioemotional wealth. Entrepreneurship Theory and Practice. 2014(38): 713-720.

[6]. ZongHui Li, Joshua J. Understanding family firm innovation heterogeneity. Journal of Family Business Management. 2016(6): 103-121. 